\title{
Developing Teaching Material Complex Procedure Text Based on Literacy Learning in Senior High School
}

\author{
Monalisa Frince S \\ Indonesian Language Education and Literature \\ Universitas Negeri Medan \\ Medan, Indonesia \\ sianturimonalisa@gmail.com \\ Abdurahman Adisaputera \\ Indonesian Language Education and Literature \\ Universitas Negeri Medan \\ Medan, Indonesia \\ Mutsyuhito Solin \\ Indonesian Language Education and Literature \\ Universitas Negeri Medan \\ Medan, Indonesia
}

\begin{abstract}
Teaching material are all forms of material used by teachers in teaching. Teaching material need to be developed. Today, the mastery of information is important. Learning literacy can be used to make students learn to master information through reading, writing and critical thinking. This study aims to determine the feasibility of teaching material of writing complex procedure text based on literacy learning. Research and development in this research based on the development model of Borg and Gall. The subjects of trials consisted of material expert, design expert, Indonesian teacher, the students, on individual trial consisted of 3 students, on small group trial consisted of 9 students and in on a limited field trial group consisted of 36 students. The data about the quality of the product was collected by using questionnaire and writing test. The result showed that: material validation included content feasibility with an average $94.53 \%$ on very good criteria, the feasibility of presentation with an average $90.38 \%$ on good criteria, the feasibility of language with an average $93.26 \%$ on criteria very good; design expert validation with an average $89.58 \%$ on very good criteria; individual trial with an average $84.16 \%$ on criteria very good; small group trial with an average $91.11 \%$ on criteria very good, and limited field trial group with an average $94.02 \%$ on criteria very good; the effectiveness teaching material with presentation $\mathbf{8 0 . 2 8 \%}$ on criteria good. Thus, teaching material which has been developed is feasible to be used as learning source.
\end{abstract}

Keywords-developing teaching material; complex procedure text; literacy learning

\section{INTRODUCTION}

Learning process in a class cannot be separated from the use on teaching material. Teaching material used as a source and learning. Teaching material is a set information which is understood by the students, to create meaningful learning process. Iskandarwassid and Sunendar (2009:171) states that teaching material is a set of information which has to be mastered by the students through fun learning [1]. Therefore, teaching material should be appropriate with the need and the students' condition. The students' atmosphere is often faced with some information that required the students to respond the information correctly. The world development at this era asks everyone to be able to think critically and smart in responding the information and also active to look for the truth of an information.

Facts that occur in the field, teaching materials used by students contain about various types of text that are described using general information. Results of student needs analysis that the information contained in teaching materials is not relevant for students. Some of the information described in the text does not match the student's life situation.

The second fact that is found is in the implementation in the classroom, the teacher has difficulty to build context to the students due to the lack of learning resources and teaching materials supporting the student's book. Other facts also show that teachers lack innovation to develop teaching materials and have the assumption that developing teaching materials is difficult. Prastowo (2015: 14) points out, the prevailing paradigm and perception among educators is to make teaching materials a difficult job [2]. Teachers are still centered on textbooks used by schools without being creative to develop student books.

One of the learning materials of Indonesian language is the text of complex procedures. Kemdikbud (2014: 36) states that the text of complex procedures is a text that contains steps or steps that must be taken to achieve the goal [3]. Meanwhile, 
Derewianka (2004: 23-27) explain procedure text is already familiar with people's daily life, for example in giving instructions to make something, in games rules, in recipes, manual steps, directions of destination [4]. Therefore, it can be concluded that the text of procedure is a text that is not strange in everyday life contains about guidance / direction to do something with a sequence or steps complete, clear and detailed. The instructions can be simple instructions, recipes, travel plans and more

The problem found in the school and strengthened by doing observation, the researcher was interested to develop the teaching material for complex procedure text which refers to the information fitted with the students' real life. The information would be processed and discussed by integrating reading and writing competence added by the competence to think critically. The integration of two competences and thinking critically is called as literacy competence. It is confirmed by Suherli (2009) that literacy competence includes discourse understanding, competence in comprehending the listening, speaking, reading, writing and thinking, competence in mastering new idea as a supporter of success in academic environment and social, competence in performance of reading and writing and competence academically in understanding a discourse professionally [5].

Literacy is really needed so the students get used to think critically in interpreting meaning in spoken or written. Kemdikbud (2016) explains that the government also runs the literacy learning in a program named Gerakan Literasi Sekolah (School Literary Action) [6]. The implementation is emphasized on all learning subjects. However, it will be better if it can be implemented based on the development of teaching material in order it could help the students.

Choosing literacy as the basic development of teaching material refers to Suyono's statement (2009) entitled "Effective and Productive Learning based on Literacy : Analysis context, principle, and alternative strategy of its implementation in the school." It is explained that literacy can be used as a base of developing effective and productive learning which allow the students to read well, look for and process information [7]. Besides that, it explained that based on the context, principle and appropriate literacy can be used as a base learning to help the students process the information by reading, writing, and think critically.

This research development is carried out to create a product in form of teaching module. Module is a selfsupporting teaching material made to help the students in understanding the learning material with or without the teacher's attendance. Module can be used as the main teaching material or supporting a text book. Module is designed as well as possible with an explanation that could ease the students to understand the material. In line with what Prastowo (2015:107) states that the existence of a module is able to make the students to study individually without the teacher who is ready in every learning process [2].

The research development of teaching material complex procedure text based on literacy learning was designed so the teaching material produced is valid to be used by the teachers and the students in the learning process in accordance with the characteristic and potential in the school so it could improve the understanding and students' achievement. This research was begun by describing the construction of teaching material based on the students' need in mastering and producing complex procedure text. The research was expected could help the students in studying, thinking critically, having well literacy competence, helping and motivating the teachers to create a teaching material that could help them teach easily.

The aims of this research were (1) to construct the development of teaching material of complex procedure text based on literacy learning (2) to describe the validation of of teaching material of complex procedure text based on literacy learning (3) the effectiveness teaching material of writing complex procedure text based on literacy learning.

\section{METHOD}

This research employed research development approach, it was the development module of complex procedure text based on literacy learning. This development research referred to the development theory of teaching material by Borg and Gall (in Tegeh, et all 2014) in his book entitled Metode Penelitian Pengembangan (Method of Research Development) [8]. This research was conducted amounted 36 students of grade $\mathrm{X}$ Senior High School (SMA) Negeri 1 Raya Kahean. The product of teaching material developed was a module of writing complex procedure text. The research development generally can be divided into three procedures, they are the model of development product, procedure of development product, and trial of product. This research development module was carried out based on the need analysis referred to literacy learning. Tegeh et al $(2014,7)$ states that in developing teaching material, a researcher adopted it based on model of Borg and Gall because the development design is used to develop a product [8].

\section{RESULT}

The development of module writing complex procedure text based on literacy learning in this research was a module development which was modified on the process implementation of teaching material by involving the literacy components on the learning which consisted of (1) collecting information, (2) processing information and (3) communicating information (Subandiyah, 2015) [9]. The writing material of complex procedure text would be collaborated on these three literacy components. The worksheet in this module was made by integrating skills in language added by thinking critically. It was expected it could be a meaningful learning because the students tended to be critique to be able to write complex procedure text. Like the following picture. 


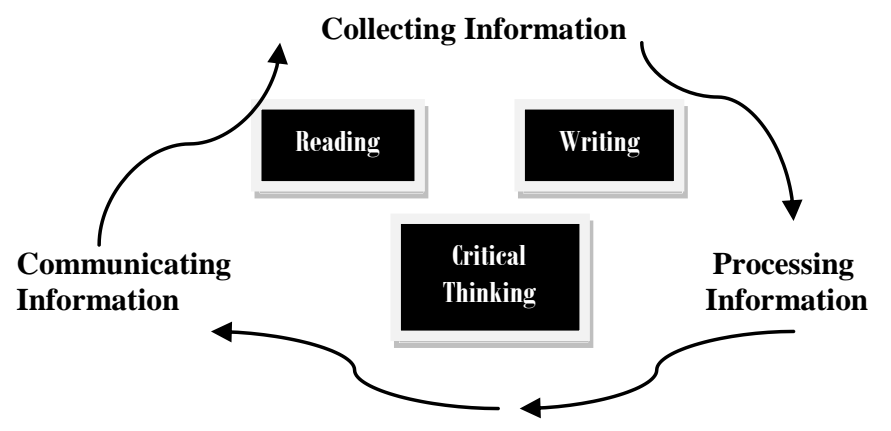

"Fig 1. Illustration Developing Teaching Material Complex Procedure Text Based on Literacy Learning"

Research and development was done in order to produce a product that was module of writing complex procedure text based on literacy and also to test the effectiveness and feasibility the product which could be used by the students SMA, as a way of improving the quality of learning. Thus, the process of this research and development was done and begun by applying some steps, they were:

(1) doing preliminary study through observing and literature study. From the observation result, the data obtained that the students really needed teaching material such as module. The results of preliminary study of needs analysis with observations made it turns out that there are still many students who are not interested in text writing skills, students still can not put their contents and ideas into written form, students do not understand the text of complex procedures on textbooks used, and less availability learning resources to increase students' knowledge in writing by giving questionnaires to students and teachers about their introduction to modules and the extent to which they require self-modulated teaching material on writing complex procedure text. Based on the questionnaire data, only $95 \%$ of students who know the learning materials in the form of modules, $100 \%$ of students never use the teaching materials in the form of modules and $100 \%$ of students answered require teaching materials in the form of modules. While the teacher, $100 \%$ familiar with the teaching material in the form of module, $100 \%$ never use the module, and $100 \%$ require the module.

Table 1. Need Assesment

\begin{tabular}{|l|c|c|c|c|c|}
\hline \multirow{2}{*}{ Question } & Ans & \multicolumn{3}{|c|}{ Frequency } & \multirow{2}{*}{$\begin{array}{c}\text { Perce } \\
\text { ntage }\end{array}$} \\
\cline { 3 - 5 } & wer & $\begin{array}{l}\text { Te } \\
\text { ac } \\
\text { her }\end{array}$ & $\begin{array}{c}\text { Stud } \\
\text { ent }\end{array}$ & $\begin{array}{c}\text { Am } \\
\text { ou } \\
\text { nt }\end{array}$ & \\
\hline $\begin{array}{l}\text { Are you } \\
\text { familiar with } \\
\text { learning } \\
\text { materials in } \\
\text { the form of } \\
\text { modules? }\end{array}$ & Yes & 2 & 2 & 4 & $100 \%$ \\
\cline { 2 - 5 } & No & - & 36 & 36 & $95 \%$ \\
\hline
\end{tabular}

\begin{tabular}{|l|c|c|c|c|c|}
\hline $\begin{array}{l}\text { Have you } \\
\text { ever used } \\
\text { instructional } \\
\text { materials in } \\
\text { the form of } \\
\text { modules? }\end{array}$ & Yes & - & - & - & - \\
\cline { 2 - 6 } & No & 2 & 36 & 38 & $100 \%$ \\
\hline $\begin{array}{l}\text { Do you need } \\
\text { instructional } \\
\text { material in } \\
\text { the form of } \\
\text { modules, } \\
\text { especially on } \\
\text { writing } \\
\text { complex } \\
\text { procedure } \\
\text { text based on } \\
\text { literacy } \\
\text { learning? }\end{array}$ & Yes & 2 & 36 & 38 & $100 \%$ \\
\cline { 2 - 6 } & No & - & - & - & - \\
\hline
\end{tabular}

(2) designing the product to produce the initial product of teaching learning. This activity included the foreword, standard competence and base competence, learning activities and references. Designing the learning activities including learning material, summary, test, key answers.

(3) Validating and revising it, these activities included evaluating the product to know deeply the strengths and weaknesses of the content of the product and the design done by the material expert and design expert. From the evaluation results will be used as material for product revision.

The validation results of the material experts showed that the feasibility of the contents with an average of $94.53 \%$ on the criteria very good, the feasibility of presentation with an average of $90,38 \%$ on the criteria very good, and the language feasibility with an average of $93.26 \%$ on the criteria very good. Thus, the module developed as a whole was in the criteria very good.

Table 2. Validation Material Expert

\begin{tabular}{|l|c|c|}
\hline \multicolumn{1}{|c|}{ Indicator } & Percentage & Criteria \\
\hline $\begin{array}{l}\text { The feasibility of the } \\
\text { contents }\end{array}$ & $94,53 \%$ & Very Good \\
\hline $\begin{array}{l}\text { The feasibility of } \\
\text { presentation }\end{array}$ & $90,38 \%$ & Very Good \\
\hline The languange feasibility & $93,26 \%$ & Very Good \\
\hline
\end{tabular}

The validation results of the design experts on the design feasibility in the development of module was in the category very good with an average percentage of $89.58 \%$. The total percentage size design of the teaching material was $100 \%$, and the total percentage gained on the cover design was $92.41 \%$.

Tabel 3. Validation Design Expert

\begin{tabular}{|l|c|c|}
\hline \multicolumn{1}{|c|}{ Indicator } & Percentage & Criteria \\
\hline Size design & $100 \%$ & Very Good \\
\hline Cover Design & $92,41 \%$ & Very Good \\
\hline
\end{tabular}


Thus, the feasibility of the design of teaching material in the form of a module of writing complex procedure text based on literacy learning was in the category very good. The results of the questionnaire of the teachers' response, stated that the module developed for the students SMA was appropriate with the needs of students and teachers with an average percentage of $97.79 \%$ on very good criteria.

(4) Conducting individual trials, small group trials, and limited field trial so it was produced an appropriate modules to be used. The data obtained from the students that the module of writing complex procedure text based on the literacy learning developed showed that (1) the average percentage of individual trials was $84.16 \%$ with very good criteria, (2) the average percentage of trials the small group was $91.11 \%$ with very good criteria, and (3) the average percentage of the limited field group test was $94.02 \%$ with very good criteria. The data on students' response to the modules developed increased by $6.95 \%$ from individual testing to small group trials, and an increase of $2.91 \%$ from small group trials to limited group trials.

Table 4. Student Trial Response

\begin{tabular}{|l|c|c|}
\hline \multicolumn{1}{|c|}{ Response } & Percentage & Criteria \\
\hline Individual trials & $84,16 \%$ & Very Good \\
\hline Small group trials & $91,11 \%$ & Very Good \\
\hline Limited field group test & $94,02 \%$ & Very Good \\
\hline
\end{tabular}

(5) Examine the effectiveness of teaching materials writing complex procedure texts on 36 students who use teaching materials and who do not use teaching materials. The result of the data obtained from the product trial to know the effectiveness of the product on 36 students who taught by using teaching materials developed was higher than the students' learning outcomes who taught by using teaching materials with textbooks. The students' achievement taught by using teaching materials developed was with an average score of 80.28 , while the students' achievement taught by using textbook materials was with an average score of 70.14. Then it can be stated that the developed material more effectively used as a source of learning in writing complex procedure text.

\section{CONCLUSION}

Based on the objectives, the results in this research development of the module of writing complex procedure text based on literacy learning on the students of SMA previously mentioned can be summarized as follows:

1. The products in the form of modules which had been developed on the material of writing complex procedure text based on literacy learning was qualify and eligible to be used. Based on the validation of material expert included content feasibility with an average of $94.53 \%$ on very good criteria, presentation feasibility with an average of $90.38 \%$ on very good criteria, and language eligibility with an average of 93.26 on very good criteria. Based on the validation of design experts it was gained an average of $89.58 \%$ on very good criteria.

2. The module pattern developed in the material of writing complex procedure text based on the literacy learning was very good and appropriate with the needs of the students. Based on the responses from 2 Indonesian teachers in SMA, the data obtained was with an average of $97.79 \%$ on very good criteria.

3. The average percentage of individual trials was $84.16 \%$ with very good criteria. The average percentage of small group trials was $91.11 \%$ with very good criteria. The average percentage of the limited field group test was $94.02 \%$ with very good criteria. The data from students' response to modules developed increased by $6.95 \%$ from individual testing to small group trials, and an increase of $2.91 \%$ from small group trials to limited group trials.

4. The achievement of 36 students showed that the average score obtained by students using teaching materials developed was 80.28 , it was higher than the average score obtained by students using textbook teaching materials, it was 70.14 .

\section{REFERENCE}

[1] Iskandarwassid dan Dadang Suhendar. (2009). Perspektif Pembelajaran. Bandung: PT Remaja Rosda.

[2] Prastowo, Andi. (2015). Panduan Kreatif Membuat Bahan Ajar Inovatif. Yogyakarta: Diva Press.

[3] Kemdikbud. (2014). Bahasa Indonesia: Ekspresi Diri dan Akademik Kelas X. Jakarta: Kemdikbud.

[4] Derewianka, Beverly. 2004. Exploris How Texts Work. Australia: Primary English Teaching Association.

[5] Suherli. (2009). Membangun Budaya Literasi. (online) (http://suherlicentre.blogspot.co.id/2009/11/membangun-budaya literasi.html?m=1) diakses pada 3 Maret 2017.

[6] Kemdikbud. (2016). Gerakan Literasi Sekolah untuk SMA. Jakarta: Kemdikbud.

[7] Suyono. (2006). Pengembangan Perilaku Berliterasi Siswa Berbasis Kegiatan Ilmiah: Hasil-hasil Penelitian dan Implementasinya di Sekolah. Jurnal Ilmu Pendidikan, Jilid 13, Nomor 2, Juni 2016 hlm.81-90.

[8] Tegeh, I Made, dkk. (2014). Model Penelitian Pengembangan. Yogyakarta: Graha Ilmu.

[9] Subandiyah. (2015). Pembelajaran Literasi dalam Mata Pelajaran Bahasa Indonesia. (online), 111-123

http://ejournal.fbs.unesa.ac.id/index.php/Paramasastra/article/download/27 132) diaksespada 3 Maret 2017. 